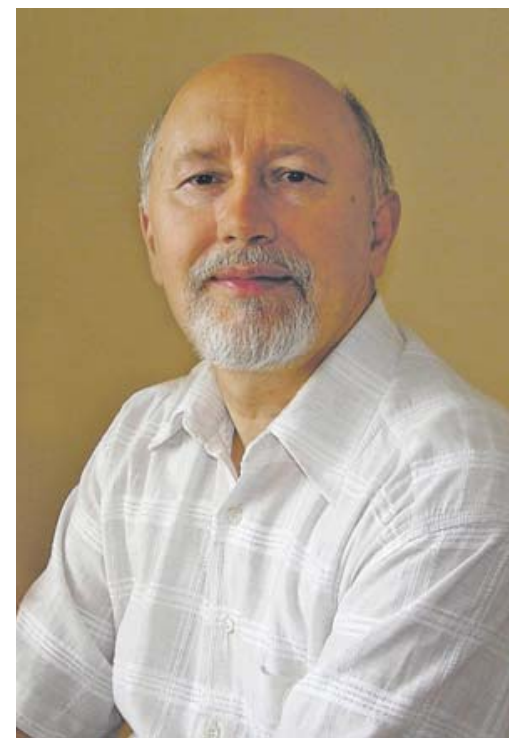

ДІдух

Яків Петрович академік НАН України, завідувач відділу геоботаніки та екології Інституту ботаніки ім. М.Г. Холодного НАН України

\section{НАУКОВІ ЗАСАДИ ФІТОБІОТИЧНОЇ СТРАТЕГIÏ ЗБЕРЕЖЕННЯ НАВКОЛИШНЬОГО СЕРЕДОВИЩА В СУЧАСНИХ УМОВАХ}

\author{
Стенограма доповіді на засіданні Президії \\ НАН України 27 жовтня 2021 року
}

\begin{abstract}
У доповіді акцентовано увагу на актуальності й гостроті проблеми втрати біорізноманіття в умовах змін клімату та інтенсивного антропогенно$2 о$ впливу. Наведено результати досліджень установ НАН України, які свідчать про значущість рослинного світу та необхідність його збереження як ключового компонента біосфери, який забезпечує ї збалансоване функиіонування та розвиток. Наголошено, що неможливо стабілізувати зміни клімату, не зберігаючи і не рятуючи при цьому біосферу. Слід відмовитися від системи утилітарної класифікації відносин між людиною та природою, побудованої на основі використання, експлуатащії, а не збереження природних ресурсів. Обгрунтовано необхідність розроблення фітобіотичної стратегії збереження навколишнвого середовища та запропоновано низку першорядних завдань, які сприятимуть приєднанню України до Європейського зеленого курсу.
\end{abstract}

Вельмишановний Анатолію Глібовичу!

Вельмишановні члени Президії НАН України!

Дякую за можливість обговорити важливі питання, пов'язані з розробленням фітобіотичної стратегії збереження навколишнього середовища, актуальність яких, мабуть, складно перебільшити. Сьогодні вже майже не залишилося сумнівів у тому, що зміни клімату зумовлюють зміни в біосфері, яка при цьому набуває такого турбулентного стану, що, якщо його не стабілізувати, це може призвести до катастрофічних наслідків.

Усі природні процеси визначаються енергетичними потоками. До ключових кількісних показників, які корелюють з показниками енергії, належать характеристики вмісту сполук карбону. I хоча запаси вуглецю в біоті наземних екосистем становлять лише 9 \% від загальних, проте саме біота є тією ланкою, яка за мільйони років забезпечила запаси карбону в грунті, горючих корисних копалинах, в атмосфері і, власне, визначає наявність життя та існування людини на планеті. 
Проблема порушення рівноваги балансу карбону набуває особливої гостроти у зв'язку 3 кліматичними змінами, посиленням антропогенного впливу, що зумовлює негативний синергетичний процес. Незважаючи на те, що Генеральна Асамблея ООН проголосила Декаду збереження біорізноманіття на період 3 2011 по 2020 р., ситуацію стабілізувати не вдалося - втрати фітобіоти зростають унаслідок кліматичних та антропогенних змін і можуть стати катастрофічними.

Масштаби змін довкілля в другій половині XX ст. стали настільки значними, що вчені запропонували виокремити навіть новий геологічний період - антропоцен, у якому людська діяльність почала відігравати істотну роль в екосистемі Землі. Початком умовного відліку антропоцену вважають 1950 рік, а сутність його полягає в тому, що людська цивілізація стала такою геофізичною силою, яка змінює організацію та структуру біосфери і зумовлює напрям подальшого розвитку еволюційних процесів. Оскільки людина впливає практично на всі планетарні процеси, вона має взяти на себе відповідальність за наслідки цього впливу. Людство зобов'язане не лише адаптуватися до зазначених змін, а й усвідомити свою відповідальність і подбати про «спадок», який воно залишає прийдешнім поколінням.

Про актуальність питань змін клімату свідчить велика кількість представницьких міжнародних форумів, самітів, конференцій та значущість рішень, прийнятих на них. Серед ключових міжнародних документів слід відзначити Рамкову конвенцію ООН зі змін клімату (Ріоде-Жанейро, 1992), Кіотський протокол (1997), який набув чинності лише в 2005 р., Паризьку угоду (хартію), дія якої розпочалася з 2020 р. Однак екологи досить гостро критикують усі ці документи, оскільки не бачать конкретних результатів, які могли б кардинально змінити ситуацію. Останніми роками людство все ж почало усвідомлювати, що лише технічними засобами та фінансовими механізмами екологічні проблеми вирішити не вдасться, потрібен глобальний і всебічний аналіз проблеми в цілому, оцінка ролі клімату у функціонуванні біосфе- ри. В цьому аспекті великі надії покладають на Конференцію ООН зі зміни клімату, відому як кліматичний саміт СОР26, який розпочнеться 31 жовтня 2021 р. у Глазго.

Науковим підгрунтям для проведення зазначених вище заходів є п'ятирічні звіти Міжурядової групи експертів ООН з питань зміни клімату (IPCC). Зараз завершується підготовка 6-го такого звіту, в роботі над яким беруть участь троє українських науковців, зокрема й сьогоднішній доповідач. У цьому звіті чітко наголошено, що головною і безумовною причиною глобального потепління є антропогенна діяльність, а кліматичні катастрофи - це їі наслідки. Причому ці процеси прискорюються: останні 5 років були найспекотнішими за всю історію спостережень з 1850 р., а підвищення температури на $1,5{ }^{\circ} \mathrm{C}$ буде досягнуто вже до 2040 р., однак, якщо найближчим часом не вдасться скоротити обсяги викидів парникових газів, цей поріг буде подолано раніше. Вчені прогнозують збільшення кількості фаз екстремальної спеки та зміну тривалості певних періодів. Не буде на планеті жодного куточка, де можна було б сховатися від наслідків глобального потепління. I не варто думати, що це проблеми лише державного рівня, вони безпосередньо стосуються діяльності кожної людини. Ефективна реалізація заходів щодо протидії змінам клімату потребує формування певного типу екологічної свідомості, чого поки що бракує людству.

В Україні основними державними нормативними документами з питань змін клімату є Закони України «Про охорону навколишнього природного середовища» i «Про Основні засади (стратегію) державної екологічної політики України на період до 2020 року»; розпорядження Кабінету Міністрів України «Про затвердження плану заходів щодо виконання Концепції реалізації державної політики у сфері зміни клімату на період до 2030 року», «Про схвалення Концепції Державної науково-технічної програми у сфері зміни клімату до 2030 року» $\mathrm{i}$ «Про схвалення Стратегії екологічної безпеки та адаптації до зміни клімату на період до 2030 року», а також підготовлений законо- 
проєкт про території Смарагдової мережі. Слід зазначити, що останніми роками діяльність вищих органів державної влади з цього напряму дещо активізувалася.

НАН України також не залишається осторонь вирішення важливих проблем у сфері збереження біорізноманіття. Так, створено Координаційну раду НАН України з проблем, пов’язаних з Рамковою конвенцією ООН про зміну клімату, Академія бере участь у Програмі ЮНЕСКО «Людина і біосфера», основними цілями якої є визначення економічних, соціальних та екологічних наслідків втрати біорізноманіття і створення мережі біосферних резерватів з метою скорочення таких втрат. Виконуються цільова комплексна міждисциплінарна програма наукових досліджень НАН України «Фундаментальні засади прогнозування та упередження негативного впливу змін кліматичних умов на біотичні системи України» (2017-2021), цільова комплексна міждисциплінарна програма наукових досліджень НАН України з проблем сталого розвитку та раціонального природокористування в умовах глобальних змін навколишнього середовища (2020-2024). Крім того, 27 листопада 2020 р. Президія НАН України прийняла рішення про необхідність розроблення Державної науковотехнічної програми у сфері змін клімату.

Ці питання вже обговорювалися на засіданнях Президії НАН України, але сьогодні я хотів би привернути вашу увагу до не менш значущого аспекту цієї проблеми. Клімат - це динамічний компонент біосфери, що характеризується високою лабільністю, релевантністю, здатністю до швидкого відновлення. На сучасному етапі клімат зазнає флуктуаційних змін, характеризується турбулентними процесами, подальше посилення яких може призвести до катастрофічних наслідків. Клімат є тригерним механізмом, який впливає на велику кількість різних процесів, але водночас він залежить від зворотної реакції екосистем. Прямий вплив клімату не такий катастрофічний, як опосередкований. Доведено, шо стресові ситуації є більш лімітаційно значущими, ніж тенденція змін до певної межі.
Отже, ключовим меседжем моєї доповіді є теза, що не можна стабілізувати зміни клімату, не зберігаючи і не рятуючи при цьому біосферу. Для обгрунтування цього твердження ми виносимо на обговорення такі три аспекти:

1) протидіяти кліматичним змінам неможливо без оцінки взаємозалежності всіх компонентів біосфери, оскільки клімат залежить від їх зворотної реакції, а це означає, що потрібен глобальний і всебічний аналіз ролі клімату у функціонуванні біосфери;

2) механізм протидії кліматичним змінам пов'язаний не лише з обмеженням викидів в атмосферу, регулюванням вмісту в ній парникових газів та скороченням енергетичних витрат; не менш важливим є регулювання балансу емісії та депонування вуглецю, збільшення запасів енергї екосистемами та оптимізація їi витрат;

3) важливо також оцінювати роль фітобіоти (фітостроми) у біосферних процесах не лише як стабілізувального чинника, а й як індикатора таких змін.

Тезу про те, що біотичний компонент, зокрема рослинний світ, є основою екосистем і відіграє ключову роль у функціонуванні біосфери, переконливо довів у своїх працях В.I. Вернадський. Що ж до проблеми регулювання балансу між емісією і акумуляцією та накопичення екосистемами запасів енергії, для їі вирішення важливо знати всі джерела емісії, всі наявні загрози кліматогенних змін та їх можливі негативні наслідки для природи. Для України можна виокремити 13 таких основних загроз:

- підвищення температури, збільшення кількості днів з високою температурою, зростання ймовірності посух у літній період;

- збільшення кількості і масштабів лісових пожеж;

- збільшення частоти і тривалості пожеж на торфовищах;

- усихання лісів через зниження вологості грунту;

- зоонози, епізоотії, епіфітотії, збільшення кількості хвороб рослин і тварин локального і регіонального поширення;

- «цвітіння» водойм, їх евтрофікація;

ISSN 1027-3239. Visn. Nac. Acad. Nauk Ukr. 2021. (12) 
- експансія адвентивних (заносних) видів, серед яких є чимало збудників хвороб;

- скорочення популяцій рідкісних видів, їх зникнення, що призводить до втрати біорізноманіття;

- деградація, фрагментація природних біотопів, що стримує здійснення природних функцій екосистем;

- заростання степів чагарниками, що спричиняє процеси опідзолення, перешкоджає гумусоутворенню і призводить до втрати родючості чорноземів;

- засолення грунтів у південних регіонах 3 негативними наслідками для сільського господарства і погіршенням умов проживання населення;

- зниження врожайності сільськогосподарських культур, що зумовлює продовольчі втрати та економічні збитки.

Біота по-різному реагує на кліматичні зміни. Це можуть бути швидкі реакції на сезонні чи короткочасні зміни клімату, такі як зсув початку і завершення вегетації, фенологічні зміни, зокрема у квітуванні, флуктуаційні зміни, поява однорічників, сезонна та щорічна зміна домінуючої ролі трав'яних рослин. Як приклад можна навести аномальне квітування, яке було зафіксовано у 80 видів рослин в період 2019/2020 pр., коли не наступала метеорологічна зима. Реакція на довготривалі зміни клімату проявляється в появі та інвазії нових, у тому числі адвентивних, видів, розширенні ареалів окремих видів, зміні їх адаптивних властивостей та поведінки, сукцесійних процесах, збільшенні кількості хвороб, а також у зникненні видів з їхніх оселищ або навіть вимиранні.

Доведено, що рослинні угруповання (фітоценози), в яких рослини закономірно поєднані одні з одними, значно більш чутливі до зміни зовнішніх чинників, ніж окремі види, і мають цінні індикаторні особливості. На основі оцінки зовнішніх умов, зокрема й кліматичних, за характеристиками фітоценозу ми розробили методику синфітоіндикації, а також програму для автоматизації процесу розрахунку 12 бальних показників екологічних факторів, з яких 4- кліматичні.
За результатами наших досліджень було встановлено характер кореляції між кліматичними показниками, гідрорежимом і хімічними властивостями грунту. Показано, що ці залежності можуть суттєво різнитися для різних регіонів, а отже, при вивченні навіть такого глобального чинника, як клімат, результати, отримані, скажімо, для регіону Атлантики, не можна переносити на територію України. Це означає, що необхідно проводити регіональні дослідження з урахуванням локальної специфіки. Для України виділено чотири біокліматичні регіони: 1) гумідний лісовий та лісостеповий; 2) аридний степовий; 3) гірський карпатський; 4) субсередземноморський гірськокримський, межі між якими внаслідок кліматичних змін можуть зміститися.

3 використанням зазначеної методики було встановлено, що підвищення середньорічної температури на одну й ту саму величину $\left(+1^{\circ} \mathrm{C}\right)$ по-різному впливає на показники різних природних чинників (рис. 1).

Найбільших змін зазнають показники терморежиму, омброрежиму (співвідношення опадів та випаровування) клімату, вологості та кислотності грунтів. Розроблені прогнози грунтуються на даних ретроспективного аналізу минулих років та оцінки кореляційних багатофакторних зв'язків 3 використанням сучасних методів (кореляційний, градієнтний аналізи).

За результатами аналізу такого складного багатокомпонентного взаємозв'язку встановлено нелінійний характер розвитку екосистем, який на певних етапах характеризується якісними стрибкоподібними змінами та каскадними процесами. Це пояснюється критичною межею дії кожного фактора, коли його характеристики досягають певного порогу (точки біфуркації), за межами якого навіть незначні зміни спричиняють якісні стрибкоподібні пертурбації, які важко передбачити, спрогнозувати. Це найбільш складне питання, яке сьогодні обговорюють екологи, але ймовірність формування екосистем цілком нового типу, зокрема й небажаних для людини, уже ні в кого не викликає сумнівів. 


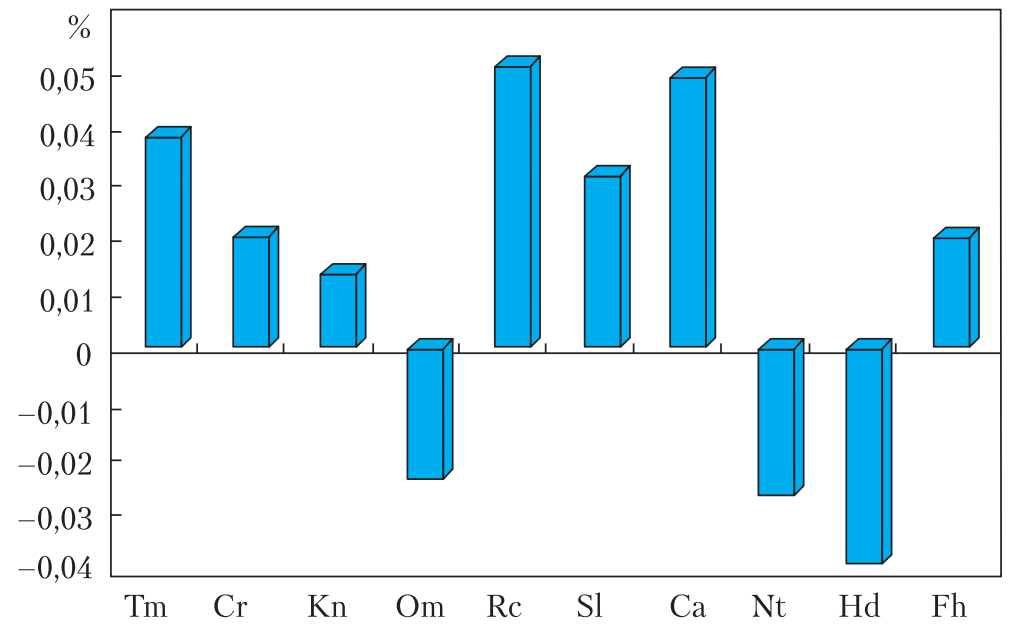

Puc. 1. Зміна показників при підвищенні середньорічної температури на $1^{\circ} \mathrm{C}$ : $\mathrm{Tm}$ - терморежим; $\mathrm{Cr}$ - кріорежим; $\mathrm{Kn}$ - континентальність клімату; Om омброрежим; Rc - кислотність грунту; $\mathrm{Sl}$ - сольовий режим; Са - вміст карбонатів; $\mathrm{Nt}$ - вміст нітрогенів; $\mathrm{Hd}$ - водний режим; $\mathrm{Fh}-$ змінність сезонного зволоження грунту
Світові експерти зазначають, що підвищення температури може призвести до катастрофічних наслідків для біоти, зокрема до зникнення видів із 40 \% оселищ їх нинішнього існування. Навіть якщо зменшити цей прогнозний показник удвічі - до 20 \%, все одно наслідки перебувають за межами стабільності екосистеми.

Для України ми розрахували середні значення меж ризиків змін (зон допустимого ризику) та можливої втрати (зон катастрофічного ризику) для оселищ 330 модельних рідкісних, занесених до «Червоної книги України» видів рослин, які є найбільш чутливими до змін клімату, за кількома сценаріями підвищення середньорічної температури - на $1 ; 2 ; 2,5$ і $3{ }^{\circ} \mathrm{C}$. Результати свідчать, що для більшості видів найголовнішими ризиками є зміна кислотності грунтів (213 видів), зміна терморежиму (206 видів), вологості (169 видів) і омброрежиму (140 видів), тобто для умов зростання опосередкований вплив зміни клімату має більше лімітаційне значення, ніж прямий. Число видів, що реагують на підвищення температури на $1^{\circ} \mathrm{C}$, становить 46, переважно це степові, петрофітно-степові, петрофітні, тобто ксерофітні, види, меншою мірою - види інших еколого-ценотичних умов. За підвищення середньорічної температури на $2^{\circ} \mathrm{C}$ кількість видів 3 ризиком втрати оселищ зростає приблизно до 40 , на $2,5^{\circ} \mathrm{C}$ - до 65 , на $3^{\circ} \mathrm{C}$ - до 80. При цьому кількість видів, що перебувають у зоні допус- тимого ризику за підвищення температури на $2,5^{\circ} \mathrm{C}$, сягає $70 \%$, а на $3^{\circ} \mathrm{C}-80 \%$. Отже, саме в межах від 1,5 до 2,5 C відбуваються найбільші зміни і найбільші втрати оселищ.

Така біоіндикаційна ознака є важливим аргументом, який показує, чому не можна допустити підвищення середньорічних температур вище $1,5^{\circ} \mathrm{C}$.

Однак для інвазійних видів потепління клімату, навпаки, є сприятливим чинником. Ці види, розширюючи ареал, здатні проникати у природні та напівприродні рослинні угруповання і трансформувати їх. Вони мають значний вплив на розвиток і відновлення популяції аборигенних видів, їхню поведінку важко контролювати. Інвазійні види впливають на режими освітлення, зволоження, хімічний склад грунтів, зумовлюючи їх виснаження i висушування, трансформують біотопи, порушують консорційні зв’язки, продуктивність ценозів, перебіг біогеохімічних процесів та інші функції екосистем. Серед таких видів багато шкідливих для людини, наприклад відомі всім амброзія полинолиста, борщівник Сосновського, гринделія розчепірена тощо. Високий потенціал інвазійних видів зумовлений тим, що в природних регіонах Північної Америки та Східної Азії вони зростають у такому самому кліматичному діапазоні, а в європейських регіонах заселяють вільну еконішу, яка утворилася внаслідок порушення структури при-

ISSN 1027-3239. Visn. Nac. Acad. Nauk Ukr. 2021. (12) 
родних ценозів та послаблення конкуренції, i через відсутність обмежувальних бар'єрів часто посідають домінуючі позиції. Механізм цих процесів досить складний і на сьогодні маловивчений, оскільки потребує комплексних досліджень зміни властивостей грунту та грунтових мікроценозів.

Інша група видів - це південні рослини, які внаслідок кліматичних змін розширюють свій ареал на північ. На сьогодні налічуються сотні таких видів, на відміну від поодиноких випадків міграцій на південь.

Загалом Україна є територією, де інвазійні процеси відбуваються досить інтенсивно, і сучасні тенденції зміни клімату разом з антропогенним впливом значно посилюють їх, аж до загрозливого рівня.

Значні зміни прогнозуються для угруповань. Результати наших досліджень свідчать, що хвойні ліси загалом є стійкими до кліматичних змін. Соснові ліси на сухих та бідних грунтах можуть навіть виявляти ознаки експансії, однак на багатших субстратах, особливо на місцях пожеж чи штучних насаджень, сосни часто втрачають свої позиції, і їх замінюють листяні породи. Крім того, сосна та ялина, яка має поверхневу кореневу систему, виявилися чутливими до погіршення гідрорежиму, внаслідок чого порушуються їх функціональні процеси, вони стають вразливі до хвороб, шкідників, патогенів і поступово всихають. Тому можна зробити загальний висновок, що в Україні площі хвойних лісів у майбутньому значно скоротяться, переважно внаслідок опосередкованого впливу змін клімату.

Для багатьох типів листяних лісів фіксують сукцесійні зміни різного характеру. При достатньому зволоженні і багатстві грунтів в угрупованнях дубових спостерігається посилення евтрофікації і, як наслідок, заміщення порід деревостану в напрямі від дубів до граба, ясена та липи, а в останні десятиліття високий рівень експансії виявляють клени, хоча раніше кленових лісів не фіксувалося. При цьому спостерігається всихання дубових лісів, а ясен перебуває під загрозою повного зникнення. Зокрема, на материковій Україні фактично вже втрачено геміксерофільні ліси дуба пухнастого, які ще в 70-х роках XX ст. фіксувалися в Одеській області, і роль клімату в цих процесах є ключовою.

Відбувається вселення у природні ліси інтродукованих видів. Особливу загрозу становить дуб червоний, посадки якого в лісах практикувалися у великих масштабах, а тепер спостерігається його інтенсивна експансія у прилеглих ценозах. Під кронами цього дерева формується потужна підстилка, яка дуже повільно розкладається. Тому тут не з'являється трав'яний покрив, тобто збіднюється флористичне різноманіття, а в сухий період накопичення підстилки створює пожежонебезпечне середовище. У містах, покинутих населених пунктах, занедбаних садах, на смітниках та в інших місцях накопичення органіки формуються умови підвищеної евтрофності, що сприяє інтенсивному заростанню адвентивними видами. Найбільш характерно це проявляється у Чорнобильській зоні, де площі таких угруповань збільшуються і набувають квазістабільного характеру. На півдні України спостерігається розширення площ, зайнятих маслинкою, робінією, айлантом високим, в'язом низьким тощо. I хоча більшість цих видів мають відносно недовгий період розвитку, вони формують умови для заселення інших, невластивих для природних ценозів порід, що призводить до скорочення площ і навіть зникнення природних лісів.

Можна очікувати, що в перспективі угруповання адвентивних порід будуть краще адаптованими до нових умов і набуватимуть квазістабільного характеру, оскільки фіксується їх інтенсивне розширення від окремих локалітетів у 1950-1980-х роках до великих площ і вихід на регіональний рівень, коли популяції заселяють сотні гектарів і поширюються далі. Отже, кліматичні зміни досить сильно і негативно впливають на розподіл та структуру ценозів. Як вважають лісівники (А.З. Швиденко $з$ колегами), навіть за найкращих сценаріїв змін клімату майже на всій території рівнинної України кліматичні умови будуть мало сприятливими для вирощування лісів, а степові та 


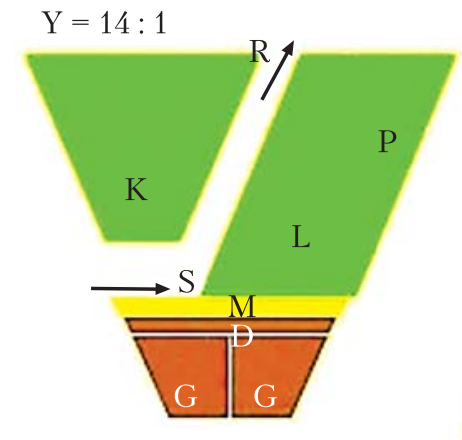

$a$

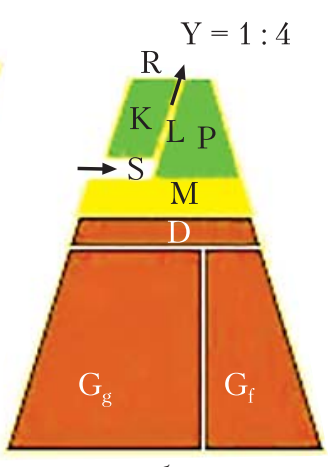

б

$\boldsymbol{P u c . ~ 2 . ~ П о р і в н я л ь н а ~ о ц і н к а ~ е н е р г е т и ч н и х ~ п о к а з н и к і в ~}$ різних компонентів лісових (a) та степових (б) екосистем: К - енергія відчуженої біомаси консументами, L - валова енергія біомаси, Р - енергія приросту, M - енергія опаду, D - енергія детриту, R - енергія дихання, $\mathrm{G}_{\mathrm{g}}$ - енергія гумінових кислот у грунті, $\mathrm{G}_{\mathrm{f}}-$ енергія фульвокислот у грунті, S - енергія синтезу, $\mathrm{Y}$ - ступінь стійкості екосистем (співвідношення енергії біомаси та грунту)

частина лісостепових територій стануть непридатними для цього. Це призведе до більш ніж дворазового скорочення обсягів поглинання вуглецевих сполук, а в глобальному масштабі - до погіршення вуглецевого балансу біосфери. Водночас це негативно впливатиме і на гідрологічний режим, оскільки ліси відіграють важливу водорегулювальну роль.

Степи як зональний тип рослинності в Україні були практично знищені ще в XIX ст. на плакорних рівнинних площах унаслідок їх тотального господарського освоєння. Лише незначні ділянки збереглися на схилах балок, берегів річок, а також на заповідних територіях. При цьому якщо в лісах механізм регулювання енергетичних потоків і збереження енергетичного балансу зосереджено в надземній біомасі (деревині), то у степах - у підземній, у найродючіших чорноземних грунтах (рис. 2), які під впливом зміни клімату знижують енергетичні вуглецево-азотні запаси.

Результати наших досліджень свідчать, що степи, як і ліси, прямо та опосередковано реагують на зміни клімату, насамперед терморежиму, а до зміни кріорежиму є навіть більш чутливими, ніж ліси. Проте, оскільки ці угруповання адаптовані до дефіциту вологи, до

зміни омброрежиму вони менш чутливі. Встановлено характер кореляції між показниками різних екофакторів, передусім тісну взаємозалежність між терморежимом та кислотністю грунтів, їх сольовим режимом, що в умовах дефіциту вологи має значно більше лімітаційне значення, ніж для лісів. Найбільш чутливими до змін зовнішнього середовища є степи 3онального типу з домінуванням усіх видів ковили, угруповання яких у разі підвищення середньорічних температур на $2,5{ }^{\circ} \mathrm{C}$ уже можуть зазнавати трансформацій через зміну кислотності грунтів.

Менш чутливими до підвищень температури є лучно-степові та різнотравно-степові угруповання. Однак для них є інші загрози останніми роками спостерігається їх інтенсивне заростання чагарниками та специфічними деревними видами, зокрема адвентивного характеру. Водночас штучні посадки лісів у природних степових ценозах не лише не підвищують енергетичні запаси, а, навпаки, порушують наявний енергетичний баланс у бік зниження, оскільки найбільші запаси енергї в степах концентруються у чорноземі. Тому намагання розширити площі лісів, висаджуючи дерева на степових ділянках, є шкідливим, на чому акцентовано увагу у шостому звіті IPCC.

Високогірні угруповання альпійського і субальпійського поясів Карпат, на відміну від інших типів біотопів, зовсім інакше реагують на зміну клімату. Найбільш загрозливим фактором у високогір'ях є зміна гідрологічного режиму грунту, що проявляється навіть за підвищення середньорічних температур на $1{ }^{\circ} \mathrm{C}$, тобто уже сьогодні є реальністю. Дійсно, вже зараз ми спостерігаємо експансію ялини в субальпійський пояс до 200 м. За підвищення температури на $2,5{ }^{\circ} \mathrm{C}$ свої позиції можуть втратити типові для альпійського поясу угруповання, оскільки в українських Карпатах висоти обмежені 2000 м над рівнем моря.

Вже відбувається й надалі посилюватиметься деградація боліт, які акумулюють величезні запаси карбону в торфі і регулюють гідрорежим. При осушенні торф’яників депонований карбон надходить в атмосферу. Багато нега-

ISSN 1027-3239. Visn. Nac. Acad. Nauk Ukr. 2021. (12) 
тивних процесів зафіксовано й на водоймах, зокрема евтрофікацію, поширення адвентивних, у тому числі навіть тропічних, видів рослин, а деякі природні види, такі як, наприклад, водяний горіх, який був у Червоній книзі, настільки збільшили свою популяцію, що тепер доводиться вживати заходів для боротьби 3 ними.

Отже, найбільш чутливими є зональні угруповання лісового, степового типу, а також високогірні та петрофітні угруповання, верхові болота, які не мають запасних «плацдармів» для відступу. Отримані результати свідчать про можливі суттєві зміни рослинного покриву регіонального характеру, які відображають зональні особливості природи України. За даними кліматологів, перетин критичної межі може відбутися в період від 2040 до 2090 р. залежно від різних сценаріїв зміни клімату.

Що ж потрібно робити, щоб зберегти біосферу для майбутніх поколінь? На наш погляд, слід запровадити якісно нові підходи до порятунку біосфери, засновані на глибшому і глобальнішому розумінні природних процесів, природних законів, тобто необхідно задіяти весь можливий суспільний і природний потенціал. Дієвим механізмом є нова екологічна парадигма - Європейський зелений курс. Причому це не лише зелена енергетика, на чому часто акцентують увагу в Україні, а й нова екологічна ідея, яка передбачає широке запровадження екологічних, економічних, техногенних, соціальних, політичних заходів, серед яких захист природи, зокрема рослинного світу, збереження біорізноманіття, що може забезпечити врівноваження процесів функціонування біосфери.

Слід відмовитися від системи утилітарної класифікації відносин між людиною та природою, побудованої на основі використання, експлуатаціі, а не збереження природних ресурсів. Необхідно взяти за основу європейську класифікацію біотопів (угідь) EUNIS, в основу якої покладено екологічні принципи іх оцінки.

Крім екологічної політики Європейський зелений курс спрямований на поглиблення співпраці з $\mathrm{CC}$ в рамках ініціативи Східного партнерства. Його суть полягає в розробленні і впровадженні комплексної програми, яка б передбачала створення відповідних юридичних документів, переорієнтацію окремих секторів економіки, заходи із забезпечення невиснажливого використання й відновлення природних та біотичних ресурсів і мала б на меті збереження та нарощування ресурсноенергетичного потенціалу. При цьому акцент слід зробити не на боротьбі зі змінами клімату, а на адаптації до них та запровадженні механізмів реагування для мінімізації їх негативного впливу.

Заходи 3 охорони екосистем і біорізноманіття передбачають розширення заповідних об'єктів, а також узгодження територій Смарагдової мережі із західноєвропейською мережею Natura-2000.

Україна хоча й намагається приєднатися до цього курсу, однак ефективність і результативність цього процесу є незадовільною. Проблема полягає в тому, що імплементація в рамках Угоди з СС у нас найчастіше закінчується розробленням нормативних документів, які не можуть бути впроваджені в практику через відсутність відповідних механізмів. I навіть на етапі розроблення документів на найвищому законодавчому рівні чиняться певні перешкоди. Як приклад можна навести блокування закону про формування Смарагдової мережі, який має прямий стосунок до кліматичних змін, оскільки, з одного боку, спрямований на збереження природних екосистем як депонентів і стабілізаторів енергетичних процесів, розширення заповідних об'єктів до загальноєвропейських показників, а з іншого - $є$ продовженням інституційного ланцюга Natura-2000 щодо формування цілісної системи охорони біорізноманіття та міжнародної співпраці 3 країнами ЄС з цього питання. Це означає, що наше суспільство в цілому і депутатський корпус та органи виконавчої влади зокрема не усвідомлюють актуальність цих екологічних проблем.

Незважаючи на те, що в Україні створюються нові заповідні об'єкти, країна рухається в 
протилежному напрямі, оскільки приватизація земель у нас часто призводить до захоплення і розорювання заповідних територій, крутосхилів, заплав тощо. I це не поодинокі випадки, а масове явище. Потрібні механізми протидії таким тенденціям. Розширення заповідних об'єктів має відбуватися з урахуванням не лише територіальних таксономічно-ценотичних підходів до охорони природи, а й насамперед функціонально-екосистемних (геотопічних), що означає запровадження таких принципів: 1) системність; 2) різноманітність; 3) репрезентативність; 4) розмірність; 5) екологічність; 6) функціональність; 7) регуляторність; 8) науковість; 9) еталонність; 10) організованість (структурованість); 11) цінність (значущість); 12) інформативність.

Необхідно також запровадити картування біотопів з оцінкою екосистемних послуг, що має стати основою для створення кадастру, підготовки паспортів-характеристик на кожний біотоп та охоронних зобов'язань землевласників, що передбачають чіткі механізми компенсації та підвищення їхньої відповідальності за завдання збитків або знищення екосистем.

3 огляду на сказане вище, для збереження природних екосистем ми запропонували низку першорядних завдань, таких як:

- створення екологічних коридорів пан'європейської екологічної мережі Natura-2000 та іiі аналога у Східній Європі - Смарагдової мережі;

- внесення змін до закону про природно-заповідний фонд, розширення площ і категорій заповідних об'єктів;

- розширення системи біосферних резерватів, створення нової категорії - екологічних заповідників з гнучким режимом заповідання, які мають стати базою для екологічного моніторингу стану довкілля;

- створення кадастру природних біотопів як частини кадастру природних ресурсів та формування червоного списку найуразливіших біотопів;

- запровадження паспортів-характеристик природних екосистем (біотопів) і охоронних зобов'язань щодо збереження цих екосистем;

- розроблення плану дій та заходів щодо збереження рідкісних видів, угруповань та біотопів;

- розроблення заходів щодо протидії інвазіям адвентивних видів рослин і тварин;

- розроблення заходів щодо збереження видів, протидії їх втратам, невиснажливого використання та відновлення лісових, степових, болотних та інших природних екосистем;

- запровадження комплексної оцінки екосистемних послуг природних біотопів.

Дякую за увагу!

За матеріалами засідання підготувала О.О. Мележик

\section{Yakiv P. Didukh}

Kholodny Institute of Botany of the National Academy of Sciences of Ukraine, Kyiv, Ukraine ORCID: https://orcid.org/0000-0001-7619-0283

\section{SCIENTIFIC PRINCIPLES OF PHYTOBIOTIC STRATEGY FOR ENVIRONMENTAL PROTECTION IN MODERN CONDITIONS}

Transcript of the report at the meeting of the Presidium of NAS of Ukraine, October 27, 2021

The report focuses on the urgency and severity of the problem of biodiversity loss in the context of climate change and intense anthropogenic impact. The results of research of the institutions of the National Academy of Sciences of Ukraine are given; they indicate the importance of flora and the need to preserve it as a key component of the biosphere, which ensures its balanced functioning and development. It is emphasized that it is impossible to stabilize climate change without preserving and saving the biosphere. It is necessary to abandon the system of utilitarian classification of relations between man and nature, built on the use, exploitation, rather than conservation of natural resources. The necessity of developing a phytobiotic strategy for environmental protection is substantiated and a number of priority tasks which will promote Ukraine's accession to the European Green Deal are proposed.

Keywords: climate change, anthropogenic pressure, biodiversity conservation, phytobiotic strategy, European Green Deal. 